\title{
LABTICĪGA ĪPAŠNIEKA TIESĪBU UZ ĪPAŠUMU AIZSARDZĪBA MANTAS İPAŠĀS KONFISKĀCIJAS PROCESĀ
}

\section{DEFENSE OF BONA FIDE OWNER'S RIGHT TO PROPERTY IN SPECIAL CONFISCATION PROCEEDINGS}

\author{
Vadims Reinfelds, $M g$. iur. \\ Latvijas Universitātes Juridiskās fakultātes doktorants
}

\section{Summary}

The article contains the analysis of special confiscation on the basis of a legal presumption of the criminal origin of the assets, a process similar in substance to nonconviction-based asset forfeiture, civil confiscation or action in rem in other countries. In order for confiscation not to violate the fundamental right to property, the state must defend the legitimate interests of innocent owners. A democratic state must find a balance between the interests of those who may have claims for seized asset in criminal proceedings - the victim, bona fide owner and the state. The main conclusions of the article are that the bona fide owner must be protected from the special confiscation of assets, this right is based on the general principles of law, primarily upon the right to property, the Constitution of Latvia (Satversme), international treaties and judgments of the ECtHR. Special confiscation of assets from a bona fide owner is not permissible. The criminal origin of an asset is not a perpetual characteristic of the asset, it ends with the acquisition in good faith by an innocent owner.

Atslēgvārdi: labticīgs īpašnieks, tiesības uz īpašumu, mantas īpašā konfiskācija, noziedzīga manta, legālā prezumpcija

Keywords: bona fide owner, right to property, special confiscation (non-conviction based asset forfeiture), criminal assets, legal presumption

\section{Ievads}

Rakstā analizētas labticīgo trešo personu iespējas aizsargāt savas tiesības uz ipašumu mantas īpašās konfiskācijas procesā. Ar terminu "labticīgs ìpašnieks" vai "labticīgs ieguvējs" šajā rakstā tiek domāta persona, kas labā ticībā ieguvusi mantu, par kuru kriminālprocesā tiek lemts par konfiskāciju. Ar jēdzienu "mantas īpašās konfiskācijas process" šajā darbā autors saprot ne tikai atsevišķi izdalīto procesu par noziedzīgi iegūtu mantu, bet jebkuru kriminālprocesu, kura ietvaros labticīgam īpašniekam var tikt piemērota mantas īpašā konfiskācija vai kurā labticīga ieguvēja tiesības konfliktē ar cietušā tiesībām uz mantu. 
Reālā mantas īpašās konfiskācijas politika Latvijā liecina, ka bezskaidras naudas un citu finanšu līdzekḷu arests un konfiskācija ir apjomīgākais šajā procesā iesaistītās mantas veids. Finanšu līdzekḷu (t. i., bezskaidras naudas, finanšu instrumentu) kā mantas statuss šajā publikācijā tiek īpaši izcelts arī tāpēc, ka labticīga īpašnieka tiesību apjoms var būt atškirīgs atkarībā no tā, vai manta ir ķermeniska un neatvietojama vai bezķermeniska un atvietojama lieta. Saskaņā ar Finanšu izlūkošanas dienesta (turpmāk - FID) datiem 2018. gadā šì dienesta iesaldēto finanšu līdzekḷu apjoms bija 101,48 miljoni eiro, ${ }^{1}$ savukārt 2019. gada laikā FID iesaldēto līdzekḷu apmērs ir sasniedzis vēsturisku rekordu - 345,98 miljonus eiro, ${ }^{2}$ neskaitot citu valsts struktūru veiktos finanšu līdzekḷu arestus. Mantas ìpašā konfiskācija attiecībā uz finanšu lìdzekḷiem faktiski vienmēr ir saistīta ar noziedzīgi iegūtu līdzekḷu legalizēšanu, kas ir Krimināllikuma 195. pantā norādìtā noziedzīgā nodarījuma priekšmets, savukārt, lai pierādītu noziedzīgi iegūtu līdzekḷu legalizēšanu, nav nepieciešams pierādìt, konkrēti no kura noziedzīga nodarījuma līdzekḷi iegūti. ${ }^{3}$ Tas noved pie divām problēmām. Pirmā - nepierādot konkrētā noziedzīgā nodarījuma izdarīšanu, netiek konstatēts arī cietušais. Otrā - nenoskaidrojot un nepierādot konkrēto noziedzīgo nodarījumu apstākḷus, netiek ievērots proporcionalitātes jeb samērīguma princips - īpašajai konfiskācijai jāpakḷauj tikai noziedzīgi iegūta vai ar noziedzīgiem nodarïjumiem tieši saistīta manta, nevis manta, par kuras izcelsmi persona nevar sniegt pietiekamus pierādijumus (izṇemot gadījumus, kas minēti Krimināllikuma $70 .{ }^{11}$ panta otrajā un trešajā daḷā). Tas noved pie situācijas, ka šobrīd Latvijā tiek arestēti un pakḷauti mantas īpašās konfiskācijas riskam ne tikai noziedzīgi iegūti, bet arī neskaidras izcelsmes finanšu līdzekḷi, kas atrodas pie personām, kurām netiek uzrādītas apsūdzības nedz mantiskos noziegumos, nedz dalībā organizētā grupā vai saistībā ar terorismu, nedz arī tiek piedēvētas ǵimeniskas, saimnieciskas vai citādas mantiskas attiecības ar šādām personām.

Demokrātiskai un tiesiskai valstij jānodrošina interešu līdzsvars starp mantas īpašās konfiskācijas procesā iesaistītajām personām, kuras var pretendēt uz arestēto mantu - cietušo, mantas labticīgo ieguvēju un valsti. Pašlaik notiekošie procesi Latvijā saistībā gan ar mantas īpašās konfiskācijas piemērošanu, gan ar normatīvo aktu grozī̌sanu, paplašinot valsts pilnvaras šajā procesā, liek pievērst īpašu uzmanỉbu labticīgo personu ìpašuma tiesību aizsardzībai.

\section{Labas ticibas princips}

Civillikuma 1. pantā noteikts, ka tiesības izlietojamas un pienākumi pildāmi pēc labas ticības. ${ }^{4}$ Analizējot labticīgas trešās personas statusu mantas ìpašās konfiskācijas procesā, ir jānoskaidro šādi jautājumi: 1) labticīguma jēdziens; 2) mantas ieguvēja labticīguma nozìme un juridiskās sekas.

1 Noziedzīgi iegūtu līdzekḷu legalizācijas novēršanas dienesta 2018. gada pārskats. Rīgā, 2019. gada 31. martā. Pieejams: https://www.fid.gov.lv/images/Downloads/about/reports/KD_2018_g_atskaite.pdf [aplūkots 01.03.2020.].

2 FID preses relīze. 2019. gada Finanšu izlūkošanas dienesta svarīgākie uzdevumi. Pieejams: https:// lvportals.lv/dienaskartiba/313393-2019-gada-finansu-izlukosanas-dienesta-svarigakie-uzdevumi-2020 [aplūkots 01.03.2020.].

3 Krimināllikums: LV likums. Pieņemts 17.06.1998. [01.03.2020. red.].

4 Civillikums: LV likums. Pieṇemts 28.01.1937. [01.03.2020. red.]. 


\section{Labas ticības jēdziens}

Attiecībā uz labas ticības jēdziena izpratni tiesību zinātnieki runā par līdzīgām pazīmēm, kas raksturo labu ticību, - godprātība, ētikas normu ievērošana, apzināta kaitējuma neradīšana trešajām personām. Latvijas Zinātṇu akadēmijas īstenais loceklis Kalvis Torgāns norādījis, ka mūsdienu apstākḷos termina "pēc labas ticības" vietā precīzāks būtu bijis apzīmējums "godprātīgi", bet, tā kā Latvijas judikatūra tieši tā izprot un traktē šo jēdzienu, tad terminoloǵijas nerada sarežǵijumus vispārējā tiesību principa piemērošanā nedz vispārējās, nedz speciālajās civiltiesību nozarēs. ${ }^{5}$ Latvijas Augstākās tiesas Senāts norādījis, ka Civillikuma 1. pantā ietvertais labas ticības princips nostiprina vispārējā taisnīguma principu, kas prezumē personas tiesību un likumīgo interešu aizskāruma novēršanu, novirzot juridiskās nianses otrā plānā. ${ }^{6}$

Judikatūrā un arī tiesību doktrīnā pastāv stabils uzskats, ka laba ticība nav tikai paša subjekta subjektīvs vērtējums, bet gan objektīva kategorija. Tas nozīmē, ka labticīga persona ir tā, kas ne tikai nezināja par tādu apstākḷu esamību, kas tai neḷautu būt godprātīgai kādā darījumā vai situācijā, bet kas arī nevarēja zināt un kurai nevajadzēja zināt par šādu apstākḷu esamību.

\section{Mantas īpašnieka labticības nozīme mantas īpašās konfiskācijas procesā}

Labticīgam valdījumam un tā pierādīšanas nepieciešamībai mantas īpašās konfiskācijas lietās Latvijas tiesu praksē netiek piešķirta nozīme, tā tiek vērtēta tikai civilprocesā, mantas ieguvējam vai kreditoram cel̦ot prasību par zaudējumu atlīdzību. Autoram ir viedoklis, ka mantas ieguvēja labticībai vai tās trūkumam ir izšķiroša nozīme mantas ìpašās konfiskācijas procesos. Pirms pievērsties Latvijas regulējumam minētajā jautājumā, jānoskaidro jautājumi par: 1) labas ticības kā vispārējā tiesību principa nozīmi mantas īpašās konfiskācijas procesā; 2) starptautisko normatīvo aktu regulējumu; 3) labu ticību kā mantas likumīgas izcelsmes pierādījumu.

\section{Labas ticības kā vispārējā tiesību principa nozīme}

Labas ticības aizsardzība ir viens no vispārējiem tiesību principiem. Atbilstoši profesora V. Sinaiska atziṇai laba ticība ir arvien vēl tās pašas taisnības veids.? Saskaņā ar tiesību doktrīnu vispārējie tiesību principi ir patstāvīgi tiesību avoti pat tad, ja tie rakstiskajos tiesību avotos nav vārdiski izteikti. Visos gadijumos, kad ir notikusi vispārējo tiesību principu un rakstīto tiesību normu kolīzija, vispārējiem tiesību principiem ir prioritāte pār rakstīto tiesību normu, kas ir pretrunā ar tiem, jo vispārējie tiesību principi izriet no visas tiesiskās sistēmas, tie atspoguḷo šīs sistēmas garu un nosaka tās saturu. ${ }^{8}$

Satversmes tiesa ir skaidrojusi, ka gadijumā, kad tiesību normu iespējams interpretēt dažādi, jāizvēlas tā interpretācija, kura nodrošina pamattiesību aizsardzību augstākā līmenī. Tā kā vispārējie tiesību principi kalpo par leǵitimitātes kritēriju gan likumdevēja pieṇemtajām tiesību normām, gan šo normu

5 Torgāns K. Civiltiesību, komerctiesību un civilprocesa aktualitātes. Rīga: Tiesu nama aǵentūra, 2009, 209.-210. lpp.

6 Augstākās tiesas Senāta Civillietu departamenta 12.01.2005. spriedums lietā Nr. SKC-22. Augstākās tiesas Senāta Civillietu departamenta spriedumi un lēmumi. Rīga: Tiesu nama aǵentūra, 2006, 165.-169. lpp.

7 Sinaiskis V. Taisnības princips Latvijas civīltiesībās. Jurists, 1937, Nr. 7/8, 123. lpp.

8 Iḷjanova D. Vispārējo tiesību principu nozīme un piemērošana. Rīga: Ratio iuris, 2005, 118. lpp. 
interpretācijai, vispārējo tiesību principu piemērošana sekmē likuma formālā teksta iztulkošanu atbilstoši taisnīguma prasībām. ${ }^{9}$

\section{Starptautisko normativo aktu regulējums attiecībā uz labticīgo trešo personu aizsardzību}

Vislielākā uzmanība trešo personu aktīvu konfiskācijai un šo personu tiesību nodrošināšanai ir pievērsta Eiropas Parlamenta un Padomes Direktīvā Nr. 2014/42/ES par nozieguma rīku un noziedzīgi iegūtu līdzekḷu iesaldēšanu un konfiskāciju Eiropas Savienībā. ${ }^{10}$ Direktīvas 6. panta 2. punkts noteic, ka šā panta 1. punktā noteiktie trešajai personai piemērojamie konfiskācijas pasākumi "neskar bona fide trešo personu tiesības". Lìdzīgs regulējums ietverts arī citos starptautiskos tiesību aktos. ${ }^{11}$

Eiropas Cilvēktiesību tiesa saistībā ar mantas paplašināto konfiskāciju (citviet tiek lietots termins "civilā konfiskācija" vai "civilprocess in rem") vairākās lietās (piemēram, Telebis and Viziteu v. Romania, ${ }^{12}$ Gogitidze and others v. Georgia ${ }^{13}$ ) ir izteikusi šìs tiesas praksē nostabilizējušās atziṇas saistībā gan ar pierādỉjumu nastas pārlikšanu uz atbildētāju, gan konfiskācijas piemērošanu trešo personu ìpašumā esošajai mantai, attiecībā uz pēdējo norādot - konfiskācijas pasākumus var piemērot ne tikai personām, kuras tieši tur aizdomās par noziedzīgiem nodarījumiem, bet arī attiecībā uz trešajām personām, kuras nav ieguvušas îpašuma tiesības labā ticībā (Telebis and Viziteu v. Romania, \$76).

No starptautiskajiem tiesību aktiem viennozìmīgi izriet, ka mantas ìpašās konfiskācijas procesā nevar tikt aizskartas labticīgo trešo personu tiesības.

OECD savā 2018. gada ziṇojumā tieši norāda, ka labticīgo trešo personu tiesību aizsardzības standarti pagaidām nav ietverti Latvijas likumos. Šajā ziņojumā tiek citēts Latvijas Kriminālprocesa likuma 360. pants, norādot, ka, pastāvot likumā tieši noteiktajiem labticīguma nosacỉjumiem, šìm labticīgajām trešajām personām pēc būtības nav iespēju realizēt savas tiesības kriminālprocesa ietvaros. ${ }^{14}$

\section{Laba ticība kā mantas likumīgas izcelsmes pierādījums}

Jebkura noziedzīga manta ar laiku nonāk pie labticīga ieguvēja - pie tā, kas nezināja, nevarēja zināt un kam nevajadzēja zināt par mantas noziedzīgo izcelsmi. Mantas noziedzīga izcelsme neturpinās mūžīgi, bet izbeidzas ar tās labticīgu iegūšanu. Tas nozīmē, ka ar labticīgu iegūšanu tiek pārtraukts mantas

${ }^{9}$ Laviņš A. Par taisnīguma nozīmi tiesas spriešanā. Pieejams: https://www.satv.tiesa.gov.lv/articles/ satversmes-tiesas-tiesnesa-alda-lavina-raksts-par-taisniguma-nozimi-tiesas-spriesana/ [aplūkots 01.03.2020.].

${ }^{10}$ Eiropas Parlamenta un Padomes Direktīva 2014/42/ES par nozieguma rīku un noziedzīgi iegūtu lìdzekḷu iesaldēšanu un konfiskāciju Eiropas Savienībā. Pieṇemta Briselē 03.04.2014. [01.03.2020. red.].

11 Sk. ANO Pretkorupcijas konvencijas 31. panta 9. punktu. Pieņemta N̦ujorkā 31.10.2003. [01.03.2020. red.]; Eiropas Padomes konvencijas par noziedzīgi iegūtu līdzekḷu legalizācijas un terorisma finansēšanas novēršanu, kā arī šo līdzekḷu meklēšanu, izṇemšanu un konfiskāciju 8. pantu. Pieṇemta Varšavā 16.05.2005. [01.03.2020. red.].

12 ECT 26.09.2018. spriedums lietā Nr. 47911/15 Telbis and Viziteu v. Romania. Pieejams: https:// hudoc.echr.coe.int/eng\#\{\%22itemid\%22:[\%22001-184058\%22]\} [aplūkots 01.03.2020.].

13 ECT 12.05.2015. spriedums lietā Nr. 36862/05 Gogitidze and others v. Georgia. Pieejams: https:// hudoc.echr.coe.int/eng\#\{\%22itemid\%22:[\%22001-154398\%22]\} [aplūkots 01.03.2020.].

14 ОЭСР, 2018. Конфискация орудий, средств совершения и доходов от коррупционных преступлений в Восточной Европе и Центральной Азии. Pieejams: https://www.oecd.org/corruption/ acn/OECD-Confiscation-of-Proceeds-of-Corruption-Crimes-RUS.pdf [aplūkots 01.03.2020.]. 
“noziedzīga valdījuma” periods. Kāda ir šì "noziedzīgā valdījuma” perioda pārtraukšanas praktiskā nozīme? Pirmkārt, šo mantu no labticīga ieguvēja valsts nedrīkst konfiscēt, tā var tikt atdota tikai sākotnējam ìpašniekam jeb cietušajam. Otrkārt, ja mantas sākotnējais īpašnieks nevar tikt noskaidrots, tā paliek labticīgā ieguvēja īpašumā. Faktiski var teikt, ka valsts pilnvaras konfiscēt noziedzīgu mantu ir ierobežotas laikā - no brīža, kad tiek izdarìts mantisks noziedzīgs nodarījums, līdz brīdim, kad šì manta nonāk pie labticīga ieguvēja. Pārējā laikā šì manta atrodas likumīgā (nenoziedzìgā) civiltiesiskā apgrozībā, un jautājums par tās piederību izšķirams pēc civiltiesību normām.

Shematiski mantas izcelsmes transformāciju un valsts tiesību konfiscēt noziedzīgu mantu ierobežojumu laikā var attēlot šādi:

\section{Mantas izcelsmes transformācija laikā}

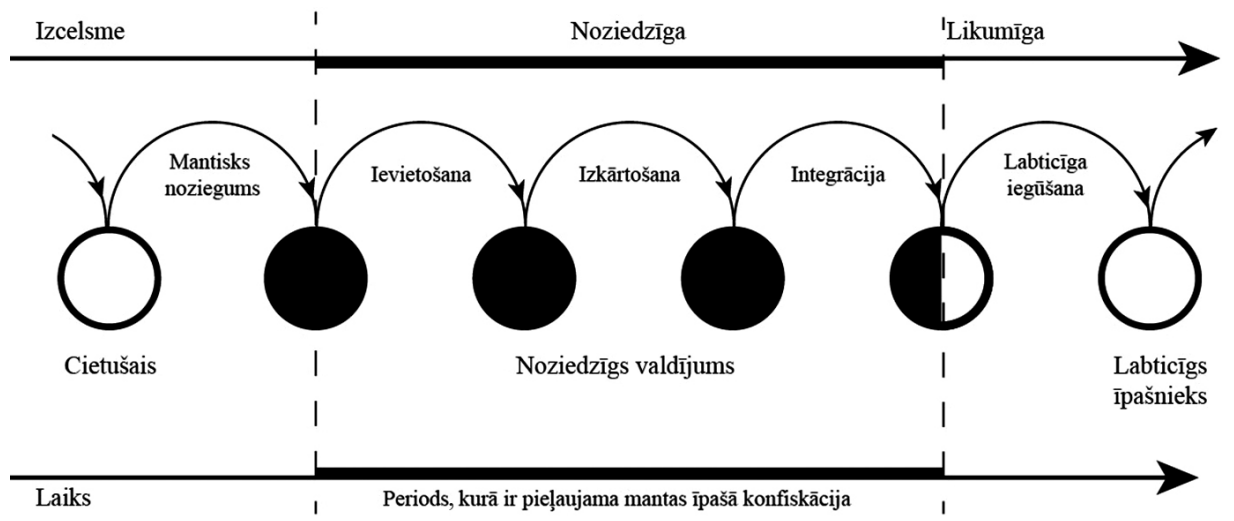

No šīs shēmas varam uzskatāmi redzēt, ka valsts tiesības konfiscēt noziedzīgu mantu ir ierobežotas laikā - ipašā konfiskācija ir piemērojama tikai "noziedzīga valdījuma" periodā. Mantai nonākot "labticīgā ìpašumā", ir piel̦aujama tikai tās "restitūcija” (atdošana cietušajam) vai atstāšana labticīgajam ieguvējam.

\section{Labas ticības pierādīšanas īpatnības ("labticības tests")}

Turpmāk rakstā tiks pievērsta uzmanība šādiem jautājumiem: 1) labas ticības pierādišanas īpatnības; 2) apstākḷi, kuri jāpierāda: a) zināšanas; b) nodoms; c) rīcība; 3) labas ticỉbas pierādī̌̌anas robežas.

\section{Labticīguma pierādīšanas īpatnības}

No iepriekš minētajām atziṇām par labticīguma jēdzienu izriet vairākas šķietami pašsaprotamas lietas. Pirmkārt, nepastāv starpposms starp labticīgu un l̦aunticīgu ieguvēju, persona konkrētajā situācijā var būt tikai vienā no šìm pusēm. Otrkārt, pastāv iespēja pierādīt labticīgumu ar argumentiem, kas izslēdz personas l̦aunticíbu, tāpat kā personas labticìgumu var atspēkot ar 
pierādījumiem par tās ḷaunticību. Treškārt, vajadzētu pieṇemt, ka valsts var uzlikt personai tikai tāda pienākuma izpildi, kas ir reāli paveicams. Ja privātpersonai tiek uzlikts pienākums pierādìt mantas likumīgo izcelsmi, kas var ietvert sevī personas labticības pierādī̌̌anu, tad nepieciešams saprast, ar kādiem līdzekliem šis pienākums ir reāli izpildāms.

\section{Apstākḷi, kuri jāpierāda: a) zināšanas; b) nodoms; c) rīcỉba}

Pēc autora ieskata, labu ticību var pierādìt ar personas zināšanām, nodomu un rīcibu:

1. Zināšanas - jāpierāda apstākḷi, kuros persona ir ieguvusi mantu no šāda redzes punkta: vai persona ir zinājusi, varēja zināt un tai vajadzēja zināt, ka mantai ir nelikumiga izcelsme.

2. Nodoms - jāpierāda personas nodoms jeb darījuma, ar kuru iegūta manta, mērkis un tas, ka tas pats par sevi ir labticìgs.

3. Rīcība - jāpierāda personas rīcība. Ja tā atbilst zināšanām un darījuma mērķim, tad persona ir rīkojusies labā ticībā.

\section{Pierādǐšanas robežas}

Svarīgi ir noskaidrot, pie kādas robežas sasniegšanas persona var atgriezt pierādīšanas pienākumu (t. i., likt pierādīt pretējo) valstij. Neskatoties uz to, ka kriminālprocesā pierādī̌sanas pienākums tiek uzlikts vienai no pusēm (standarta gadījumā - valstij, bet saistībā ar mantas likumīgas izcelsmes pierādī̌sanu - privātpersonai), tas neatcel otras puses pienākumu pierādìt faktus un apstākḷus, kas apstiprina tās pozīciju un atspēko pretējās puses pierādījumus un argumentus. Šāda konstrukcija izriet no pierādišanas teorijas un log̣ikas. Pielietojot to mantas ìpašās konfiskācijas lietās, var teikt, ka pastāv pierādīšanas robežas, līdz kurām privātpersonai ir objektīva iespēja veikt pierādīšanu. Šim apstāklim ir praktiska nozīme jautājumos, kad jāvērtē, cik tālu sniedzas mantas izcelsmes noskaidrošana. Loǵiski būtu pieņemt, ka persona objektīvi var iegūt un sniegt ziņas par mantu lìdz pēdējam darijumam ar nesaistîtu personu, un, sasniedzot šo robežu, pienākums pierādīt pretējo, t. i., to, ka mantai ir noziedzīga izcelsme, pāriet uz valsti. Papildus šādai pieejai par labu runā tas, ka valstij, atšķirībā no personas, kriminālprocesa ietvaros ir plašas iespējas un tiesības iegūt un procesuāli nostiprināt šādus pierādījumus, savukārt privātpersonai šādu iespēju nav.

\section{Labticīga īpašnieka tiesību aizsardzība mantas īpašās konfiskācijas procesā Latvijā}

Kriminālprocesa likuma 360. pants attiecībā uz trešo personu aizsardzību noteic, ka noziedzīgi iegūta manta, kas atrasta pie trešās personas, atdodama pēc piederības īpašniekam vai likumīgajam valdìtājam un ka trešajai personai, kas bija šis mantas labticīga ieguvēja vai labticīga kīlas n̦ēmēja, ir tiesības civilprocesa kārtībā iesniegt prasību par zaudējuma atlīdzināšanu, tai skaitā pret apsūdzēto vai notiesāto personu. ${ }^{15}$

${ }^{15}$ Kriminālprocesa likums: LV likums. Pieņemts 21.04.2005. [01.03.2020. red.]. 360. panta pirmā un otrā daḷa. 
Satversmes tiesas spriedumā lietā Nr. 2016-07-01'16 izteikta atziṇa, ka kriminālprocesā cietušās personas aizsardzības princips prevalē pār labticìga ieguvēja tiesībām uz ìpašumu. Te jānnem vērā, ka minētā lieta tika skatīta kontekstā ar strīdu starp cietušo un labticīgo ieguvēju par īpašuma tiesībām uz nekustamo īpašumu, tāpēc tajā izteiktās atziṇas neaptver visus iespējamos gadījumus rīcībai ar noziedzigu mantu.

Krimināllikuma $70 .{ }^{11}$ panta ceturtā daḷa noteic, ka noziedzīgi iegūtu mantu, līdzekḷus, ko persona ieguvusi no šādas mantas realizācijas, kā arī noziedzīgi iegūtas mantas izmantošanas rezultātā gūtos augḷus konfiscēe, ja tā nav jāatdod ìpašniekam vai likumīgam valdītājam.

Abas šìs normas un minētais Satversmes tiesas spriedums neattiecina izṇēmumu no labticīga ieguvēja aizsardzības uz situācijām, kurās: 1) cietušais netiek konstatēts (kas ir ierasts gadijums procesos "pret mantu") vai 2) manta ir atvietojama lieta (bezskaidra nauda, finanšu instrumenti).

No minētajām normām var secināt, ka attiecībā uz noziedzīgi iegūtu mantu Latvijā darbojas divi atškşirīgi institūti: 1) mantas atdošana īpašniekam vai likumīgam valdītājam (restitūcija) un 2) mantas īpašā konfiskācija. Turpmākajā raksta sadaḷa tiks noskaidrots labticīgas trešās personas statuss katrā no šiem procesiem un tiks modelēta procesa virzìtāja vai tiesas rīcība ar noziedzīgu mantu katrā no iespējamiem gadījumiem atkarībā no mantas ieguvēja labticības un mantas veida.

\section{Mantas atdošana īpašniekam vai likumīgam valdītājam (Kriminālprocesa likuma 360. pants)}

Tiesību teorijā un praksē pastāv nostabilizējies viedoklis, ka uz noziedzīga nodarījuma pamata iegūtu mantu ìpašuma tiesības nepāriet, līdz ar to labticīga ieguvēja ìpašuma tiesības minētajā situācijā aizsargātas netiek. Tomēr te jāṇem vērā, ka šìs normas piemērošanas nosacījumi ir līdzīgi vindikācijai civilprocesā. Šie nosacījumi ir šādi: 1) manta izgājusi no personas (cietušā) valdījuma noziedzīga nodarījuma rezultātā - tiek pierādīta noziedzīga nodarījuma izdarīšana; 2) ir konstatēts cietušais (īpašnieks vai likumīgais valdītājs); 3) ir pierādītas cietušā îpašuma tiesības uz mantu - to var izdarìt tikai attiecībā uz neatvietojamu lietu.

\section{Mantas īpašā konfiskācija (Krimināllikuma 70. ${ }^{11}$ panta ceturtā daḷa)}

Mantas īpašajai konfiskācijai tātad ir divi galvenie priekšnoteikumi. Pirmais, manta nav jāatdod īpašniekam vai likumīgam valdītājam, un otrais - mantas izcelsme ir noziedzīga.

Vispirms būtu jānoskaidro, vai ar “ipašnieku vai likumīgo valdìtāju” šeit ir jāsaprot tikai cietušais (analoğiski Kriminālprocesa likuma 360. pantam), jo gramatiski abas normas ir veidotas līdzīgi, vai tomēr arī labticīgs ieguvējs. Vai var būt situācija, kad personas labticība noziedzīgu mantu pārvērš par likumīgu? Tas notiek ikdienā un ik uz soḷa. Zaglis ar nozagto naudu pērk legālas preces un pakalpojumus, darbiniekiem tiek maksātas algas, valsts budžetā no legalizētajiem noziedzīgajiem līdzekḷiem tiek samaksāti nodokḷi, un visi, kas labticīgi ir saṇēmušas šādus naudas līdzekḷus, - tirdzniecības uzṇēmumi, pakalpojumu

\footnotetext{
${ }^{16}$ Latvijas Republikas Satversmes tiesas 08.03.2017. spriedums lietā Nr. 2016-07-01. Pieejams: http:// www.satv.tiesa.gov.lv/wp-content/uploads/2016/05/2016-07-01_Spriedums-1.pdf [aplūkots 30.12.2019.].
} 
sniedzēji, darbinieki, valsts - kḷūst par pilntiesīgiem naudas īpašniekiem, ja tās nezināja, nevarēja zināt un tām nevajadzēja zināt, ka naudai ir noziedzịga izcelsme.

Shematiski rīcíbu ar mantu kriminālprocesā var attēlot šādi atkarībā no tā, vai procesā ir iesaistīts cietušais, un atkarībā no mantas veida.

\begin{tabular}{|c|c|c|c|}
\hline \multicolumn{4}{|c|}{ RĪCĪBA AR MANTU KRIMINĀLPROCESĀ } \\
\hline \multicolumn{2}{|c|}{$\begin{array}{l}\text { Procesā iesaistītās personas } \\
\text { (saistībā ar mantu) }\end{array}$} & \multicolumn{2}{|c|}{$\begin{array}{c}\text { Mantas veids un rīcība ar mantu } \\
(\text { kam atdod vai atstāj) }\end{array}$} \\
\hline Cietušais & Labticīgs ieguvējs & $\begin{array}{l}\text { Neatvietojama } \\
\text { lieta (nekust. īpašumi, } \\
\text { transportlìdzekli, } \\
\text { mākslas darbi u. tml.) }\end{array}$ & $\begin{array}{l}\text { Atvietojama lieta } \\
\text { (nauda, finanšu } \\
\text { instrumenti, naftas } \\
\text { produkti u. tml.) }\end{array}$ \\
\hline IR & IR & $\begin{array}{c}\text { CIETUŠAIS } \\
\text { (restitūcija, iznēemums } \\
\text { no labticīga ieguvēja } \\
\text { aizsardzības) }\end{array}$ & $\begin{array}{l}\text { LABTICĪGS } \\
\text { IEGUVẼJS }\end{array}$ \\
\hline NAV & IR & $\begin{array}{l}\text { LABTICĪGS } \\
\text { IEGUVẼJS }\end{array}$ & $\begin{array}{l}\text { LABTICĪGS } \\
\text { IEGUVẼJS }\end{array}$ \\
\hline NAV & NAV & $\begin{array}{c}\text { VALSTS } \\
\text { (konfiskācija) }\end{array}$ & $\begin{array}{c}\text { VALSTS } \\
\text { (konfiskācija) }\end{array}$ \\
\hline
\end{tabular}

No minētā uzskatāmi izriet, ka mantas ìpašā konfiskācija ir piemērojama tikai gadījumā, ja procesā nav cietušā un labticīga mantas ieguvēja, kuru tiesības uz mantu ir spēcīgākas. Lìdz ar to gadījumos, kad manta atrodas pie trešās personas, tās ḷaunticības konstatēěana lïdztekus mantas noziedzīgajai izcelsmei ir galvenie priekšnoteikumi mantas īpašās konfiskācijas piemērošanai, kas ir jākonstatē tiesai.

\section{Kopsavilkums}

1. Labticīgs ìpašnieks ir jāizsargā no mantas ippašās konfiskācijas, tas izriet no vispārējiem tiesību principiem, Satversmes, starptautiskiem lïgumiem un ECT spriedumiem. Mantas īpašà konfiskācija no labticīga ieguvēja nav pielaujama.

2. Mantas noziedzịgā izcelsme neturpinās mūžìgi, bet izbeidzas ar labticīgu iegūšanu. Visa manta, sākot ar labticīgas iegūšanas brīdi un neatkarīgi no tam sekojošu darījumu skaita, ir uzskatāma par likumīgas izcelsmes mantu, kuras piederība nosakāma pēc civiltiesību normām.

3. Vienīgais izṇēmums, kad labticīgas trešās personas īpašuma tiesības aizsargātas netiek, ir noziedzīgā nodarỉjumā cietušā tiesību pārsvars. Cietušā tiesības tiek aizsargātas ar īpašuma tiesību atjaunošanu (restitūciju). Restitūcija ir piel̦aujama tikai attiecībā uz neatvietojamām lietām (nekustamie īpašumi, transportlīdzekḷi, mākslas darbi u. c.). 